\title{
Associations between polymorphic variants of the tryptophan hydroxylase 2 gene and obsessive-compulsive disorder
}

\author{
Associação entre polimorfismos do gene da triptofano \\ hidroxilase 2 e o transtorno obsessivo-compulsivo
}

\author{
Felipe Filardi da Rocha, ${ }^{1}$ Nathália Bueno Alvarenga, ${ }^{1}$ Naira Vassalo Lage, ${ }^{2}$ Marco Aurélio Romano-Silva, ${ }^{1,2,3}$ \\ Luiz Armando de Marco, ${ }^{1}$ Humberto Corrêa ${ }^{1,2,3}$ \\ ${ }^{1}$ Medicine Molecular Program, Universidade Federal de Minas Gerais (UFMG), Belo Horizonte, MG, Brazil \\ 2 Neuroscience Program, Universidade Federal de Minas Gerais (UFMG), Belo Horizonte, MG, Brazil \\ ${ }^{3}$ Department of Mental Health, Faculty of Medicine, Universidade Federal de Minas Gerais (UFMG), Belo Horizonte, MG, Brazil
}

\begin{abstract}
Objective: A substantial body of evidence suggests that obsessivecompulsive disorder has a genetic component, and substantial candidate genes for the disorder have been investigated through association analyses. A particular emphasis has been placed on genes related to the serotonergic system, which is likely to play an important role in the pathogenesis of obsessive-compulsive disorder. The gene for tryptophan hydroxylase 2, which is a rate limiting enzyme in serotonin synthesis, is considered an important candidate gene associated with psychiatric disorders. Method: Our sample consisted of 321 subjects (107 diagnosed with obsessivecompulsive disorder and 214 healthy controls), which were genotyped for eight tagSNPs (rs4448731, rs4565946, rs11179000, rs7955501, rs 10506645 , rs4760820, rs1487275 and rs10879357) covering the entire human tryptophan hydroxylase 2 gene. Statistical analyses were performed using UNPHASED, version 3.0.12, and Haploview ${ }^{\circledR}$. Results: Single markers, genotype analysis did not show a significant genetic association with obsessive-compulsive disorder. A significant association between the T-C-T (rs4448731, rs4565946, rs10506645) and C-A-T (rs4565946, rs7955501, rs 10506645) haplotypes and obsessive-compulsive disorder was observed, as well as a strong linkage disequilibrium between SNPs rs4448731 and rs4565946, and SNPs rs 10506645 and 4760820. Discussion: Our research has not demonstrated the existence of associations between the eight SNPs of TPH2 and obsessive-compulsive disorder. However, two LD and two haplotypes areas were demonstrated, thus suggesting that more studies in $\mathrm{TPH} 2$ are needed to investigate the role of tryptophan hydroxylase 2 variants in obsessive-compulsive disorder.
\end{abstract}

Descriptors: Psychiatry; Obsessive-compulsive disorder; Polymorphism, genetic; Tryptophan hydroxylase; Haplotypes

\begin{abstract}
Resumo
Objetivo: Diversos estudos demonstram que o transtorno obsessivo-compulsivo apresenta considerável contribuição genética, com diversos genes candidatos tendo sido estudados por meio de estudos de associação. Como alteraçôes do sistema serotonérgico estão associadas ao transtorno obsessivo-compulsivo, o gene da triptofano hidroxilase 2, enzima limitante da sintese da serotonina, é plausivel candidato para estudos. Método: Nossa amostra é composta de 321 sujeitos (107 pacientes com transtorno obsessivo-compulsivo e 214 controles) e investigamos oito tagSNPs (rs4448731, rs4565946, rs 11179000 , rs7955501, rs 10506645, rs4760820, rs1487275 e rs 10879357) do gene da triptofano hidroxilase 2. Análise estatística foi realizada com os programas UNPHASED e Haploview. Resultados: Análise de frequência alélica e genotípica entre casos e controles não evidenciaram diferenças estatisticamente significativas. No entanto, observamos maior prevalência dos haplótipos T-C-T (rs4448731, rs4565946, rs10506645) e C-A-T (rs4565946, rs 7955501, rs 10506645) entre os pacientes, assim como duas regiöes com importantes desequilíbrios de ligação (SNPs rs 4448731 e rs4565946; SNPs rs 10506645 e 4760820). Discussão: Nossos achados não demonstraram uma associação entre os SNPs do gene da TPH2 e o transtorno obsessivo-compulsivo, porém mais estudos são necessários, já que fortes desequilibrios de ligação foram demonstrados, assim como dois haplótipos.
\end{abstract}

Descritores: Psiquiatria; Transtorno obsessivo-compulsivo; Polimorfismo genético; Triptofano hidroxilase; Haplótipos

\section{Introduction}

A substantial body of evidence suggests that obsessivecompulsive disorder (OCD) has a genetic component, and substantial candidate genes have been investigated through association analyses. A particular emphasis has been placed on
Submitted: July 23, 2010

Accepted: August 2, 2010
Correspondence

Dr. Felipe Filardi da Rocha

Rua Sapucaia, 83 - Cond. Retiro das Pedras

35460-000 Brumadinho, MG, Brasil

Email:fil_bh@yahoo.com.br 
genes related to the serotonin system, which is likely to play an important role in the pathogenesis of OCD. ${ }^{1-4}$

The gene for tryptophan hydroxylase (TPH), the rate-limiting step in serotonin $(5-\mathrm{HT})$ synthesis, is an interesting candidate for association analyses. The TPH gene was first identified in 1990 and was believed to be unique. ${ }^{5}$ However, the presence of normal levels of 5-HT in the brains of TPH-deficient mice led to the identification of a second TPH gene (TPH2), which is predominantly expressed in the brain and regulates the effects of 5-HT in the central nervous system. ${ }^{5,6}$

Genetic variation in the TPH 2 gene may contribute to susceptibility to numerous psychiatric disorders, including major depression, ${ }^{7-9}$ panic disorder, ${ }^{10}$ suicidal behavior, and bipolar affective disorder. ${ }^{7-11}$

A review of the psychiatric literature published over the past years has shown that studies on the genetic variants of the TPH1 gene have yielded negative results. In the two studies conducted with OCD patients, results were also negative. ${ }^{3,7,12}$ These findings must be reinterpreted in view of the fact that TPH1 is responsible for 5 -HT synthesis in peripheral organs, while TPH2 controls the synthesis of 5-HT in the brain. Although only two studies investigated the role of TPH 2 in OCD, ${ }^{13,14}$ one demonstrated promising results. Mössner et al. studied two TPH2 SNPs (rs4570625 and rs4565946) and observed an important contribution of rs 4565946 to the total risk of early-onset OCD.

Based on the few studies that have assessed TPH2 and OCD and the one whose result was positive, we sought to investigate the association between OCD and eight TagSNPs of the TPH2 gene in a sample of 107 Brazilian-Caucasian OCD patients and 214 matched healthy controls.

\section{Method}

\section{Sample}

1) Patient group: 107 OCD Brazilians of Caucasian descent as determined by self and/or clinical evaluation between the ages of 18 and 65 years participated in this study. Participants satisfied DSM-IV criteria for a diagnosis of OCD and were recruited from a specialized OCD clinic at the Medical School of UFMG, Belo Horizonte-MG, Brazil, by a consultant psychiatrist. The diagnosis was made by a trained psychiatrist using the following resources: (1) the structured MINI-PLUS interview, ${ }^{15}$ which follows the DSM-IV criteria, (2) complete review of the patients' medical records, and (3) an interview with at least one close relative. We excluded participants who currently had mild/moderate/severe major depressive disorders, bipolar disorders, substance-related disorders, psychotic disorders, or a lifetime history of traumatic brain injury/vascular brain disorder.

2) Control group: 214 healthy controls were recruited among university students and locals through local advertisements and subsequently screened using the MINI-PLUS interview. The subjects were free of psychiatric illness and had no family history of Axis I psychiatric disorder in first-degree relatives (self-report). They were also of Brazilian-Caucasian descent. This data was obtained using both self-report and clinical data.
The study was completed in accordance with the guidelines of the Helsinki Declaration and approved by the local ethics committee. Subjects were given a complete description of the study before written informed consent was obtained.

\section{Genotyping}

We selected eight tagSNPs, which were provided in a made-toorder assay from Applied Biosystems TaqMan ${ }^{\circledR}$ SNP Genotyping Assays. The probes corresponded to the following polymorphisms: rs4448731 (intergenic), rs4565946 (intron 2), rs11179000 (intron 4), rs7955501 (intron 5), rs10506645 (intron 7), rs4760820 (intron 8), rs1487275 (intron 8) and rs10879357 (intron 8). All polymorphisms were chosen using Hapmap (at website: www. hapmap.org) and were selected to analyze the whole gene.

Genotyping was performed using real time PCR in a mode of allelic discrimination (Strategene Mx3005 - MxPro QPCRSoftware, 2007). PCR protocols followed the instructions of the TaqMan ${ }^{\circledR}$ Genotyping Master Mix (Applied Biosystems, Foster City, CA). The PCR conditions were 1 cycle $\left(95^{\circ} \mathrm{C}\right.$ for $\left.10 \mathrm{~min}\right)$ and 50 cycles $\left(95^{\circ} \mathrm{C}\right.$ for $15 \mathrm{~s}, 60^{\circ} \mathrm{C}$ for $\left.1 \mathrm{~min}\right)$. Protocol: $3.5 \mu \mathrm{l}$ of mix, $0.1 \mu$ l of probe, $3.4 \mu \mathrm{l}$ of deionized water and $1.0 \mu \mathrm{l}$ of DNA at a concentration of $50 \mathrm{ng} / \mu \mathrm{l}$. Retypes were done for $10 \%$ of the samples.

\section{Statistical analysis}

Statistical analyses were performed using the Unphased software package, version 3.0.12. Pairwise linkage disequilibrium was established using Haploview 4.1 software.

We used chi-square tests to compare categorical data between groups. Haplotypes frequencies were evaluated based on Bayes' theorem and Poisson distribution. A logistic regression analysis with factors such as gender and age of onset of the disorder was performed to evaluate the influence of these features on the genetic analyses.

The power to detect significant associations between cases and controls was calculated with the software Genetic Power Calculator. Based on an OCD prevalence of $2 \%$, an addictive genetic model, the number of cases and controls, and an estimated genotype relative risk of 1.5 , the power varies based on the allelic frequency of the variant and ranges from $32-56 \%$.

Results were considered significant for p-values lower than 0.05 .

\section{Results}

\section{Single marker association analysis}

We found no differences between OCD patients and controls in terms of the allele and genotype distribution of the SNPs (Table 1). All of the genotypic distributions were in Hardy-Weinberg equilibrium.

\section{Haplotype association analysis}

We observed three haplotypes. The T-C-T (rs4448731, rs4565946, rs 10506645) and the C-A-T (rs4565946, rs7955501, rs10506645) haplotypes were more frequent in patients $(\mathrm{p}<$ 0.05); Table 2. 
Table 1 - Genotype and allele frequencies in controls and OCD patients

\begin{tabular}{|c|c|c|c|c|}
\hline SNP & $\begin{array}{c}\text { Genotype and allele } \\
\text { frequencies }\end{array}$ & Controls $(n=214)$ & Patients $(n=107)$ & p \\
\hline \multirow[t]{4}{*}{ rs4448731 } & TT & $0.294(n=63)$ & $0.327(n=35)$ & $>0.05$ \\
\hline & TC & $0.509(n=109)$ & $0.495(n=53)$ & \\
\hline & $\mathrm{CC}$ & $0.196(n=42)$ & $0.158(n=17)$ & \\
\hline & $\mathrm{T} / \mathrm{C}$ & $0.549 / 0450$ & $0574 / 0406$ & $>0.05$ \\
\hline \multirow[t]{4}{*}{ rs4565946 } & $\mathrm{CC}$ & $0.373(n=80)$ & $0.364(n=39)$ & $>0.05$ \\
\hline & TC & $0.457(n=98)$ & $0.485(n=52)$ & \\
\hline & $\mathrm{TT}$ & $0.168(n=36)$ & $0.149(n=16)$ & \\
\hline & $\mathrm{C} / \mathrm{T}$ & $0.602 / 0.397$ & $0.607 / 0392$ & $>0.05$ \\
\hline \multirow[t]{4}{*}{ rs11179000 } & $A A$ & $0.453(n=97)$ & $0.467(n=50)$ & $>0.05$ \\
\hline & TA & $0.433(n=94)$ & $0.429(n=46)$ & \\
\hline & $\mathrm{TT}$ & $0.107(n=23)$ & $0.102(n=11)$ & \\
\hline & $\mathrm{A} / \mathrm{T}$ & $0.672 / 0.327$ & $0.682 / 317$ & $>0.05$ \\
\hline \multirow[t]{4}{*}{ rs7955501 } & $\mathrm{TT}$ & $0.196(n=42)$ & $0.196(n=21)$ & $>0.05$ \\
\hline & TA & $0.448(n=96)$ & $0.448(n=48)$ & \\
\hline & $A A$ & $0.355(n=72)$ & $0.355(n=38)$ & \\
\hline & T/A & $0.420 / 0560$ & $0.420 / 0.579$ & $>0.05$ \\
\hline \multirow[t]{4}{*}{ rs10506645 } & $\mathrm{TT}$ & $0.032(n=7)$ & $0.037(n=4)$ & $>0.05$ \\
\hline & TC & $0.252(n=54)$ & $0.317(n=34)$ & \\
\hline & $\mathrm{CC}$ & $0.714(n=153)$ & $0.644(n=69)$ & \\
\hline & $\mathrm{T} / \mathrm{C}$ & $0.158 / 0.841$ & $0.196 / 0.803$ & $>0.05$ \\
\hline \multirow[t]{4}{*}{ rs4760820 } & $\mathrm{CC}$ & $0.443(n=95)$ & $0.485(n=52)$ & $>0.05$ \\
\hline & GC & $0.401(n=86)$ & $0.411(n=44)$ & \\
\hline & GG & $0.154(n=33)$ & $0.102(n=11)$ & \\
\hline & $\mathrm{C} / \mathrm{G}$ & $0.642 / 0.357$ & $0.691 / 0.308$ & $>0.05$ \\
\hline \multirow[t]{4}{*}{ rs1487275 } & AA & $0.509(n=109)$ & $0.495(n=53)$ & $>0.05$ \\
\hline & CA & $0.425(n=91)$ & $0.448(n=48)$ & \\
\hline & $\mathrm{CC}$ & $0.065(n=14)$ & $0.056(n=6)$ & \\
\hline & $\mathrm{A} / \mathrm{C}$ & $0.721 / 0.278$ & $0.719 / 0.280$ & $>0.05$ \\
\hline \multirow[t]{4}{*}{ rs10879357 } & GG & $0.411(n=88)$ & $0.364(n=39)$ & $>0.05$ \\
\hline & GA & $0.420(n=90)$ & $0.467(n=50)$ & \\
\hline & $\mathrm{AA}$ & $0.168(n=36)$ & $0.168(n=18)$ & \\
\hline & $\mathrm{G} / \mathrm{A}$ & $0.621 / 0.378$ & $0.598 / 0.401$ & $>0.05$ \\
\hline
\end{tabular}

\section{Logistic regression}

Logistic regressions were performed in all association analysis to exclude the influence of the following features: gender, age of onset of disease and presence of comorbidities (anxiety disorders). No alterations were found.

\section{Linkage disequilibrium}

As all SNPs studied showed a minor allele frequency of more than $5 \%$, they are comparable to common disease susceptibility polymorphisms with power to detect LD. Strong LD was observed twice: between SNPs rs4448731 and rs4565946 and between SNPs rs 10506645 and 4760820 (Figure 1).

\section{Discussion}

Several studies have previously attempted to evaluate the association between OCD and polymorphisms in serotonergic genes. The most commonly studied polymorphism, 5-HTTLPR (serotonin-transporter-linked promoter region), is a functional insertion/deletion variant in the promoter region of SLC6A4, the gene that codes for the serotonin transporter. Although association

Table 2 - Haplotype frequencies in OCD and controls

\begin{tabular}{|c|c|c|c|c|c|c|c|c|c|c|c|}
\hline \multirow[t]{2}{*}{ Haplotype ID } & \multicolumn{8}{|c|}{ Markers } & \multicolumn{2}{|c|}{ Frequency } & \multirow[t]{2}{*}{$p^{*}$} \\
\hline & 1 & 2 & 3 & 4 & 5 & 6 & 7 & 8 & $\operatorname{OCD}(\mathbf{n}=107)$ & Controls $(n=214)$ & \\
\hline A & $\mathrm{T}$ & C & - & - & $\mathrm{T}$ & - & - & - & $0.046(n=5)$ & $0.009(n=2)$ & 0.027 \\
\hline B & - & $\mathrm{C}$ & - & $A$ & $\mathrm{~T}$ & - & - & - & $0.037(n=3)$ & $0.000(n=0)$ & 0.012 \\
\hline C & - & $\mathrm{C}$ & - & - & $\mathrm{T}$ & $G$ & - & A & $0.009(n=1)$ & $0.009(n=2)$ & 0.76 \\
\hline
\end{tabular}




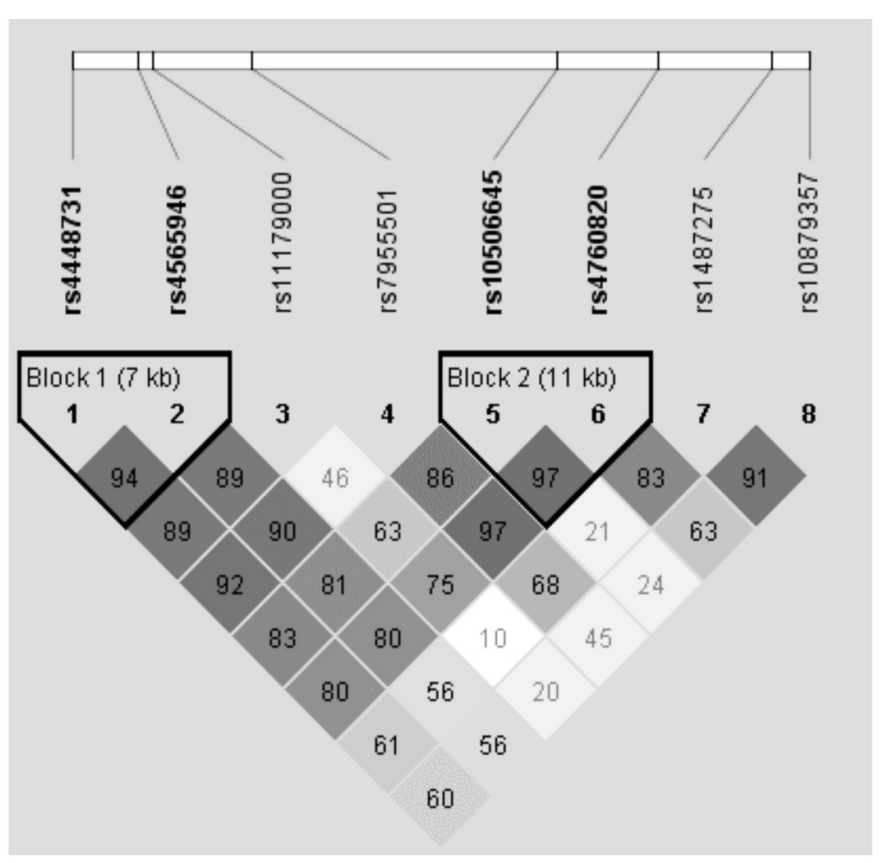

Figure 1 - LD block structure across TPH2 gene. The upper panel shows the location of eight polymorphisms in TPH2 gene and lower panel shows the output of HAPLOVIEW (v.4.1). LD plot, each square (with D' values written within the box), represents a pair wise LD relationship between the two SNPs. Red squares indicate statistically significant LD between the pair of SNPs as measured by the D' statistic. Darker colors of red indicate higher values of D', up to a maximum of 1 , and white squares indicate pairwise D' values of $<1$ with no statistically significant evidence of LD. The blocks generated (block 1 and 2) under confidence interval algorithm of HAPLOVIEW are marked. These blocks are constituted by two pairs of SNPS (rs4448731 and rs4565946; rs10506645 and rs4760820).

studies have revealed inconsistent findings, additional variants have recently been identified for this polymorphism (alleles La and Lg), notably associating the allele La with OCD. ${ }^{1,2}$

In the present study, we investigated polymorphic variants of TPH2 (which codes for the rate-limiting 5-HT synthesizing enzyme in the brain) in a sample of 107 OCD patients. Analogous to the impact of other candidate genes of the serotonergic pathway on disease risk, a small to moderate effect of polymorphic variants of TPH 2 was anticipated.

The studied SNPs are intronic. Thus, they do not affect amino acid coding and probably do not directly affect protein function. Associations between OCD patients and controls should be interpreted as the presence of LD between these SNPs and other SNPs in exons (resulting in functional polymorphism) or in regulatory regions (affecting the expression of these genes).

A significant association between the T-C-T (rs4448731, rs4565946, rs10506645) and C-A-T (rs4565946, rs7955501, rs 10506645) haplotypes was observed with OCD. Moreover, important LD was observed between two pairs of SNPs, suggesting that TPH2 should be a plausible susceptibility gene for OCD (Table 2; Figure 1).

In order to corroborate the possible association between TPH2 polymorphisms and OCD, Mössner et al. studied two TPH2 variations: two SNPs located in the putative transcriptional control region (SNP rs4570625) and in intron 2 (rs4565946). They evaluated a unique family-based sample of OCD patients with onset of the disease in childhood and adolescence comprising 71 complete independent trios. The SNPs were in LD, and early-onset OCD was related to allele C (rs4565946) transmission.

Given that this study has several methodological limitations, caution should be taken when generalizing these results. Our study may be underpowered and may be lacking the required statistical power to detect potential associations due to its small sample size. This may explain the small sample of haplotypes found. Further studies with large sample sizes estimated by power calculations are necessary to confirm the findings of the present study.

Although there is a high comorbidity of DSM-IV axis I and II disorders in OCD, not all possible comorbidities (anxiety disorders) were considered as exclusion criteria. These comorbidities, which may be associated with the serotonergic system, might have influenced our results.

Furthermore, it has become clear that OCD is not a simple and homogeneous disorder but rather a heterogeneous disorder mediated by a range of different factors including age of onset, gender, and comorbidities. ${ }^{1,2}$ Moreover, some hypothesize that there may be several additive genes, each contributing to the OCD phenotype. ${ }^{1-4}$ Thus, the chance of detecting these putative genes may be reduced in a relatively small sample of patients. Therefore, larger and more homogeneous groups are needed to achieve a more accurate characterization of the genetic component of OCD.

Finally, although our sample comprised only self-declared Caucasian Brazilians, race as determined by self and/or clinical evaluation is a poor predictor of ancestry in Brazil. Therefore, an ethnic stratification bias cannot be ruled out. ${ }^{16}$

In conclusion, our research has not demonstrated associations between the eight SNPs of TPH2 and OCD. However, it did demonstrate two LD areas and two haplotypes that were more frequent in patients, thus suggesting the need for further studies on TPH 2 to elucidate the role played by TPH2 variants in OCD. 


\section{Disclosures}

\begin{tabular}{|c|c|c|c|c|c|c|c|}
\hline $\begin{array}{l}\text { Writing group } \\
\text { member }\end{array}$ & Employment & $\begin{array}{l}\text { Research } \\
\text { grant }^{1}\end{array}$ & $\begin{array}{c}\text { Other research grant } \\
\text { or medical continuous } \\
\text { education }\end{array}$ & $\begin{array}{l}\text { Speaker's } \\
\text { honoraria }\end{array}$ & $\begin{array}{l}\text { Ownership } \\
\text { interest }\end{array}$ & $\begin{array}{l}\text { Consultant } \\
\text { Advisory } \\
\text { board }\end{array}$ & Other $^{3}$ \\
\hline $\begin{array}{l}\text { Felipe Filardi da } \\
\text { Rocha }\end{array}$ & UFMG & $\begin{array}{c}\text { CNPq }^{* * *} \\
\text { FAPEMIG*** }^{*}\end{array}$ & - & - & - & - & - \\
\hline $\begin{array}{l}\text { Nathália Bueno } \\
\text { Alvarenga }\end{array}$ & UFMG & $\begin{array}{l}\text { CNPq }^{* \star *} \\
\text { FAPEMIG*** }^{*}\end{array}$ & & & & & - \\
\hline Naira Vassalo Lage & UFMG & $\begin{array}{c}\text { CNPq }^{* * *} \\
\text { FAPEMIG*** }^{*}\end{array}$ & - & - & - & - & - \\
\hline $\begin{array}{l}\text { Marco Aurélio } \\
\text { Romano-Silva }\end{array}$ & UFMG & $\begin{array}{l}\text { CNPq }^{\star * *} \\
\text { FAPEMIG*** }^{*}\end{array}$ & - & - & - & - & - \\
\hline $\begin{array}{l}\text { Luiz Armando de } \\
\text { Marco }\end{array}$ & UFMG & $\begin{array}{c}\text { CNPq }^{* * *} \\
\text { FAPEMIG*** }^{* *}\end{array}$ & - & - & - & - & - \\
\hline Humberto Corrêa & UFMG & $\begin{array}{c}\text { CNPq }^{* * *} \\
\text { FAPEMIG*** }^{*}\end{array}$ & - & - & - & - & - \\
\hline $\begin{array}{l}\text { *Modest } \\
{ }^{* *} \text { Significant } \\
\text { ** Significant. Amour } \\
\text { author. } \\
\text { Note: UFMG = Univer } \\
\text { Fundação de Apoio à } \\
\text { For more information, }\end{array}$ & $\begin{array}{l}\text { ven to the autl } \\
\text { de Federal de } \\
\text { yuisa do Estad } \\
\text { Instructions for }\end{array}$ & $\begin{array}{l}\text { 's institution } \\
\text { las Gerais; C } \\
\text { e Minas Gera } \\
\text { thors. }\end{array}$ & $\begin{array}{l}\text { to a colleague for resear } \\
q=\text { Conselho Nacional }\end{array}$ & which the & $\begin{array}{l}\text { has particip } \\
\text { Sientífico e T }\end{array}$ & not directly & IIG = \\
\hline
\end{tabular}

References

1. da Rocha FF, Malloy-Diniz L, Lage NV, Romano-Silva MA, de Marco LA, Correa $\mathrm{H}$. Decision-making impairment is related to serotonin transporter promoter polymorphism in a sample of patients with obsessive-compulsive disorder. Behav Brain Res. 2008;195(1):159-63.

2. da Rocha FF, Romano-Silva MA, de Marco LA, Corrêa H. Obsessive-compulsive disorder and 5-HTTLPR. Rev Bras Psiquiatr. 2009;31(3):287-8.

3. Walitza S, Wewetzer C, Gerlach M, Klampfl K, Geller F, Barth N, Hahn F, Herpertz-Dahlmann B, Gössler M, Fleischhaker C, Schulz E, Hebebrand J, Warnke A, Hinney A. Transmission disequilibrium studies in children and adolescents with obsessive-compulsive disorders pertaining to polymorphisms of genes of the serotonergic pathway. J Neural Transm. 2004;111(7):817-925.

4. da Rocha FF, Malloy-Diniz L, Lage NV, Correa H. Positive association between MET allele (BDNF Val66Met polymorphism) and obsessive-compulsive disorder. Rev Bras Psiquiatr. 2010;32(3):323-4

5. Invernizzi RW. Role of TPH-2 in brain function: news from behavioral and pharmacologic studies. J Neurosci Res. 2007;85(14):3030-5.

6. Breidenthal SE, White DJ, Glatt CE. Identification of genetic variants in the neuronal form of tryptophan hydroxylase (TPH2). Psychiatr Genet. 2004;14(2):6972.

7. Han L, Nielsen DA, Rosenthal NE, Jefferson K, Kaye W, Murphy D, Altemus M, Humphries J, Cassano G, Rotondo A, Virkkunen M, Linnoila M, Goldman D. No coding variant of the tryptophan hydroxylase gene detected in seasonal affective disorder, obsessive-compulsive disorder, anorexia nervosa, and alcoholism. Biol Psychiatry. 1999;45(5):615-9.

8. Harvey M, Shink E, Tremblay M, Gagné B, Raymond C, Labbé M, Walther DJ, Bader M, Barden N. Support for the involvement of TPH2 gene in affective disorders. Mol Psychiatry. 2004;9(11):980-91.

9. Bach-Mizrachi H, Underwood MD, Tin A, Ellis SP, Mann JJ, Arango V. Elevated expression of tryptophan hydroxylase-2 mRNA at the neuronal level in the dorsal and median raphe nuclei of depressed suicides. Mol Psychiatry. 2008;13(5):507-13. 10. Kim YK, Lee HJ, Yang JC, Hwang JA, Yoon HK. A tryptophan hydroxylase 2 gene polymorphism is associated with panic disorder. Behav Genet. 2009;39(2):1705.

11. Ferreira A de A, Neves FS, da Rocha FF, Silva GS, Romano-Silva MA, Miranda DM, De Marco L, Correa H. The role of 5-HTTLPR polymorphism in antidepressant-associated mania in bipolar disorder. J Affect Disord. 2009;112(13):267-72.

12. Frisch A, Michaelovsky E, Rockah R, Amir I, Hermesh H, Laor N, Fuchs C, Zohar J, Lerer B, Buniak SF, Landa S, Poyurovsky M, Shapira B, Weizman
R. Association between obsessive-compulsive disorder and polymorphisms of genes encoding components of the serotonergic and dopaminergic pathways. Eur Neuropsychopharmacol. 2000;10(3):205-9.

13. Delorme R, Durand CM, Betancur C, Wagner M, Ruhrmann S, Grabe HJ, Nygren G, Gillberg C, Leboyer M, Bourgeron T, Courtet P, Jollant F, Buresi C, Aubry JM, Baud P, Bondolfi G, Bertschy G, Perroud N, Malafosse A. No human tryptophan hydroxylase-2 gene $\mathrm{R} 441 \mathrm{H}$ mutation in a large cohort of psychiatric patients and control subjects. Biol Psychiatry. 2006;60(2):202-3.

14. Mössner R, Walitza S, Geller F, Scherag A, Gutknecht L, Jacob C, Bogusch L, Remschmidt H, Simons M, Herpertz-Dahlmann B, Fleischhaker C, Schulz E, Warnke A, Hinney A, Wewetzer C, Lesch KP. Transmission disequilibrium of polymorphic variants in the tryptophan hydroxylase- 2 gene in children and adolescents with obsessive-compulsive disorder. Int J Neuropsychopharmacol. 2006;9(4):437-42.

15. Amorim P. Mini International Neuropsychiatric Interview (MINI): validation of a short structured diagnostic psychiatric interview. Rev Bras Psiquiatr. 2000;22(3):106-15.

16. Parra FC, Amado RC, Lambertucci JR, Rocha J, Antunes CM, Pena SD. Color and genomic ancestry in Brazilians. Proc Natl Acad Sci US A. 2003;100(1):177-82. 